Article

\title{
Trichoderma Enhances Net Photosynthesis, Water Use Efficiency, and Growth of Wheat (Triticum aestivum L.) under Salt Stress
}

\author{
Abraham Mulu Oljira ${ }^{1,2}{ }^{(0}$, Tabassum Hussain ${ }^{1,3}{ }^{(0}$, Tatoba R. Waghmode ${ }^{1}$, Huicheng Zhao ${ }^{1,2}$, \\ Hongyong Sun ${ }^{1}$, Xiaojing Liu ${ }^{1}$, Xinzhen Wang ${ }^{1}$ and Binbin Liu ${ }^{1, *}$ \\ 1 Center for Agricultural Resources Research, Key Laboratory of Agricultural Water Resources, \\ Institute of Genetics and Developmental Biology, Chinese Academy of Sciences, Shijiazhuang 050021, China; \\ abrahammulu@yahoo.com (A.M.O.); thussain@uok.edu.pk (T.H.); tatobawaghmode@yahoo.com (T.R.W.); \\ hczhao@sjziam.ac.cn (H.Z.); hysun@sjziam.ac.cn (H.S.); xjliu@sjziam.ac.cn (X.L.); \\ xzwang@sjziam.ac.cn (X.W.) \\ 2 University of Chinese Academy of Sciences, Beijing 100039, China \\ 3 Institute of Sustainable Halophyte Utilization, University of Karachi, Karachi 75270, Pakistan \\ * Correspondence: binbinliu@sjziam.ac.cn; Tel.: +86-31185817713; Fax: +86-31185815093
}

Received: 29 August 2020; Accepted: 5 October 2020; Published: 11 October 2020

\begin{abstract}
Soil salinity is one of the most important abiotic stresses limiting plant growth and productivity. The breeding of salt-tolerant wheat cultivars has substantially relieved the adverse effects of salt stress. Complementing these cultivars with growth-promoting microbes has the potential to stimulate and further enhance their salt tolerance. In this study, two fungal isolates, Th4 and Th6, and one bacterial isolate, C7, were isolated. The phylogenetic analyses suggested that these isolates were closely related to Trichoderma yunnanense, Trichoderma afroharzianum, and Bacillus licheniformis, respectively. These isolates produced indole-3-acetic acid (IAA) under salt stress (200 mM). The abilities of these isolates to enhance salt tolerance were investigated by seed coatings on salt-sensitive and salt-tolerant wheat cultivars. Salt stress (S), cultivar (C), and microbial treatment (M) significantly affected water use efficiency. The interaction effect of $\mathrm{M} \times \mathrm{S}$ significantly correlated with all photosynthetic parameters investigated. Treatments with Trichoderma isolates enhanced net photosynthesis, water use efficiency and biomass production. Principal component analysis revealed that the influences of microbial isolates on the photosynthetic parameters of the different wheat cultivars differed substantially. This study illustrated that Trichoderma isolates enhance the growth of wheat under salt stress and demonstrated the potential of using these isolates as plant biostimulants.
\end{abstract}

Keywords: Trichoderma; Bacillus; wheat; IAA; salt stress

\section{Introduction}

Soil salinization is recognized as one of the most serious threats to agricultural production [1], affecting more than one billion hectares worldwide [2]. Increased salinization is expected to affect $50 \%$ of arable land by the year 2050 [3]. Previous studies have revealed the detrimental effect of salt stress on many aspects of plant gas exchange, including net photosynthesis, transpiration rates, intercellular $\mathrm{CO}_{2}$, stomatal conductance, and water use efficiency [4,5]. The enhancement of photosynthetic gas exchange efficiency under stressful environmental conditions is critical for yield improvement [6]. In particular, the improvement of net photosynthesis and water use efficiency has attracted researchers' attention as possible approaches to optimize carbon assimilation in food crop production [7,8]. Metabolic acclimation via the synthesis of compatible solutes, including proline, has shown the potential to minimize salt-induced oxidative stress, protect the integrity of photosynthetic 
machinery (thylakoids and plasma membranes), repair damage to photosystem II, and scavenge reactive oxygen species (ROS) $[9,10]$.

Wheat is a major cereal crop in the North China Plain, and given that salinity stress has major effects on crop productivity in this area [11,12], greater attention has been given to breeding salt-tolerant cultivars over the last few decades [13]. Major advancements have been made in developing cultivars resilient to environmental stress, and evidence is still emerging for the contribution of plant-microbe interactions to the further improvement of this resistance [14-16]. The application of plant growth-promoting microbes (PGPM) has been shown to overcome problems related to salinity $[17,18]$. Certain Trichoderma and Bacillus spp. have effectively induced plant tolerance to salt stress by modulating several traits in wheat and other crops. Trichoderma longibrachiatum T6 enhanced wheat seedling tolerance to salinity, presumably through improvement of the antioxidative defense system and scavenging of excessive ROS produced by plants under salt stress [19,20]. Trichoderma harzianum improved the uptake of beneficial elements, stimulated compatible solute accumulation, and elevated the level of antioxidant enzymes in Brassica juncea L. under salt stress [21]. Similarly, Bacillus licheniformis HSW-16 ameliorated the negative effects of $\mathrm{NaCl}$ stress on wheat growth [22], and Bacillus subtilis BERA 71 inoculation improved biomass and photosynthetic pigments and reduced ROS in chickpea under saline soil conditions [23].

Plants cope with salt stress by employing several strategies, such as proline accumulation in the chloroplast and cytoplasm to maintain an external osmotic balance is one potential strategy [24,25]. A study by Hayat et al., 2012 demonstrated that optimum proline accumulation in the plant had a positive correlation with high tolerance to environmental stress [26]. However, there is contradictory information on whether the proline content of seedlings increases or decreases during plant-microbe interactions under abiotic stress. A review of the literature by Chun et al., 2018 about proline accumulation under salinity stress in plants colonized by arbuscular mycorrhizal fungi (AMF) concluded that AMF inoculation increases, decreases, or has no effect on proline accumulation in the plants [27]. Furthermore, proline is a source of carbon and nitrogen for fungi when nutrients are limited, and this may be a key survival strategy under stressful conditions [27].

Microbial seed coating is an attractive approach to counter salt stress even though it is utilized infrequently in crop protection against abiotic stresses [28]. There is a growing interest in applying seed coating technology in precision agriculture due to its convenience, ecological safety, and economic advantages [29]. Several reports have shown that seed inoculation with microbes capable of indole-3-acetic acid (IAA) secretion efficiently improved plant tolerance to salt stress [30-32]. In addition, many cultivable salt-tolerant microbial strains isolated from saline environments survive under osmotic and ionic stresses and are known to mitigate the detrimental effects induced by a variety of abiotic stresses $[33,34]$.

Studies have shown the prospective advantages of seed coating with PGPM for enhancing the productivity of crops under low-input agriculture [35,36]; however, little information is available regarding wheat seed coating with IAA producing beneficial microbes and whether the effects can ameliorate the deleterious effects of salt stress. Salt stress inhibits the production of IAA in the roots and restricts lateral root development $[37,38]$. In a prior study, IAA-secreting fungal species, such as Trichoderma, promoted Arabidopsis growth under normal and salt stress conditions $[39,40]$. Seed treatment with Bacillus spp. has the potential to induce physiological changes and protect plants under adverse environmental conditions [41].

The interaction between plants and beneficial soil microbes, including Trichoderma and Bacillus, can have a large impact on plant tolerance to salt stress. Thus, we hypothesized that the PGPM that are capable of producing IAA can promote plant growth under salt stress and enhance salt tolerance, and these effects could be reflected by altered proline accumulation and photosynthetic activity. Insights into cultivar-specific microbe interaction responses could lead to the selection of efficient isolates and open up a new avenue of research for practical applications. The objective of this study was (a) to isolate Trichoderma spp. from high saline soil and Bacillus from pig farms, (b) to determine the potential 
of these isolates for secretion of IAA under salt stress, and (c) to investigate the influence of microbial seed treatment containing these isolates on leaf proline content and photosynthetic parameters.

\section{Materials and Methods}

\subsection{Microbial Isolation and Purification}

The soil sample used for the isolation of halotolerant Trichoderma, herein referred to as "Th4 and Th6" was collected from the rhizosphere of a Tamarix chinensis Lour in a long-term phytoremediation field experimental site in Haixing County, Hebei Province, China. The soil chemical and physical properties were described in our recently published study [42]. The inoculums were isolated following serial dilution on Trichoderma Selective Media (TSM) [43]. Briefly, serial dilutions were made by suspending $0.3 \mathrm{~g}$ of soil in $29.7 \mathrm{~mL}$ of sterile distilled water. The mixture was vortexed vigorously in a $50 \mathrm{~mL}$ Falcon tube for $10 \mathrm{~min}$. After serial dilution, $100 \mu \mathrm{L}$ of the $10^{3}-10^{5}$ suspensions were pipetted onto Petri plates containing TSM, and the plates were incubated at $25^{\circ} \mathrm{C}$. After four days, Trichoderma colonies were collected with a sterile spatula and transferred to fresh Czapek Dox Agar (Himedia) for purification. Likewise, Bacillus C7 was obtained from composted manure from a pig farm located in Nanpi County, Hebei Province, China. Pig manure has been used as an organic amendment of coastal saline soil for the production of wheat [44]. Following serial dilution, $100 \mu \mathrm{L}$ of the $10^{3}-10^{5}$ dilutions were pipetted on carboxymethyl cellulose sodium salt ( $\mathrm{pH}$ 7.0) agar medium and incubated at $50{ }^{\circ} \mathrm{C}$. A beaker filled with sterilized water was placed in the incubator containing the plates to prevent the medium from drying out. Pure inoculums were obtained by picking single colonies of the isolate aseptically using a sterile inoculation loop on a clean bench.

\subsection{DNA Extraction, Phylogenetic Marker Gene Amplification, and Sequencing}

Genomic DNA of the fungal isolates was extracted from the pure isolates using an E.Z.N.A. ${ }^{\circledR}$ High-Performance Fungal DNA Kit (Omega Bio-tek, Inc., Norcross, GA, USA). The amplification of the fungal internal transcribed spacer (ITS) gene was performed using primers ITS1 (5'TCCGTAGGTGAACCTGCGG-3') and ITS4 (5'TCCTCCGCTTCTTGATTGATATGC-3') [45]. PCR was carried out in $50 \mu \mathrm{l}$ reaction volumes containing $5 \mu \mathrm{L}$ of $10 \times$ EasyTaq $^{\circledR}$ Buffer with $1 \mu \mathrm{L}$ of EasyTaq ${ }^{\circledR}$ DNA polymerase, $4 \mu \mathrm{L}$ of $2.5 \mathrm{mM}$ dNTPs, $1 \mu \mathrm{L}$ of each primer (TransGen Biotech Co., Ltd., Beijing, China), $2 \mu \mathrm{L}$ of template DNA, and $38 \mu \mathrm{L}$ of sterile double distilled water in a thermal cycler (Bio-Rad). The reaction involved initial denaturation at $95^{\circ} \mathrm{C}$ for $5 \mathrm{~min}$, followed by 30 cycles of denaturation at $94^{\circ} \mathrm{C}$ for $40 \mathrm{sec}$, annealing at $58^{\circ} \mathrm{C}$ for $40 \mathrm{sec}$, and extension at $72{ }^{\circ} \mathrm{C}$ for $4 \mathrm{sec}$, with a final extension step at $72{ }^{\circ} \mathrm{C}$ for $5 \mathrm{~min}$ [46].

Bacterial genomic DNA was extracted from a pure culture using the TIANamp Bacteria DNA Kit (TIANGEN, Biotech, Beijing Co., Ltd., Beijing, China) according to the manufacturer's protocol. PCR was conducted in $50 \mu \mathrm{L}$ reaction volumes containing $25 \mu \mathrm{l}$ of $2 \times$ GoldStar Best Master mix (TaKaRa, Biotechnology, Dalian, China), $0.3 \mu \mathrm{L}$ of each primer (TransGen Biotech Co., Ltd., Beijing, China), $2 \mu \mathrm{L}$ of template DNA, and $22.4 \mu \mathrm{L}$ of sterile double distilled water. The $16 \mathrm{~S}$ rRNA gene was amplified using the primer pair 27F (5'-AGAGTTGATCCTGGTCAG-3') and 1492R (5' - GGTTACCTTGTTACGCTT-3') [47]. The reaction involved initial denaturation at $95^{\circ} \mathrm{C}$ for $5 \mathrm{~min}$, followed by 29 cycles of denaturation at $95^{\circ} \mathrm{C}$ for $1 \mathrm{~min}$, annealing at $55^{\circ} \mathrm{C}$ for $1 \mathrm{~min}$, and extension at $72{ }^{\circ} \mathrm{C}$ for $2 \mathrm{~min}$, with a final extension step at $72{ }^{\circ} \mathrm{C}$ for $10 \mathrm{~min}$.

The PCR products were sequenced at Beijing (Sangon Biotech Co., Ltd., Shanghai, China). The nearest neighbors of each sequence were obtained through a BLASTN search of the GenBank nucleotide database [48]. Phylogenetic trees were constructed for the isolates with the neighbor-joining method using MEGA X software [49]. 


\subsection{Microbial Inoculum Preparation}

Trichoderma spore powder and Bacillus cell pellets were prepared according to methods described previously [50,51]. In brief, Trichoderma was grown on boiled wheat grain for three weeks, and the conidial masses were separated in a $50 \mathrm{~mL}$ Falcon tube by centrifugation at $9500 \times \mathrm{g}$ for $10 \mathrm{~min}$. The pelleted conidia were collected and dried under aerated and aseptic conditions for three days. The dried mass was powdered with a High-Speed Universal Disintegrator lab grinder (Model No. FW80, Huanghua Faithful Instrument Co. Ltd., China). The Bacillus isolate was incubated in $100 \mathrm{~mL}$ of LB broth media for $24 \mathrm{~h}$ at $30^{\circ} \mathrm{C}$ on a shaker at a speed of $150 \mathrm{rpm}$ (ZWY-200D, Shanghai ZHICHENG Analytical Instruments Manufacturing Co., Ltd., Shanghai, China). Approximately $30 \mathrm{~mL}$ of culture was transferred to a sterilized $50 \mathrm{~mL}$ Falcon tube and centrifuged at $4{ }^{\circ} \mathrm{C}$ and $9500 \times \mathrm{g}$ for $10 \mathrm{~min}$. The supernatant was discarded, and the cell pellet was washed three times with sterilized distilled water to remove media residue.

\subsection{Determination of Indole-3- Acetic acid Secretion}

For the determination of IAA secretion from the Th4 and Th6 isolates, $2 \mathrm{~mL}$ of spore suspension (inoculum $10^{8}$ spore $\mathrm{mL}^{-1}$ ) was grown in a $250 \mathrm{~mL}$ flask containing $200 \mathrm{~mL}$ Czapek Dox broth [30] amended with 0.5 gl-1 tryptophan and incubated at $27^{\circ} \mathrm{C}$ with shaking at $150 \mathrm{rpm}$ for six days. Similarly, $2 \mathrm{~mL}$ of $\mathrm{C} 7$ inoculum (OD $=0.6$ ) was transferred to LB broth and incubated at $27^{\circ} \mathrm{C}$ with shaking at $150 \mathrm{rpm}$ for $24 \mathrm{~h}$. The media were amended with $\mathrm{NaCl}$ concentrations of $0 \mathrm{mM} \mathrm{NaCl}$ and $200 \mathrm{mM} \mathrm{NaCl}$. After the incubation period, the biomass was removed by centrifugation for $5 \mathrm{~min}$ at $10,000 \times g$ to collect the supernatant. The IAA concentration in the culture supernatant was assessed with Salkowski reagent, and the reaction was allowed to proceed for $20 \mathrm{~min}$ in the dark [52]. The absorbance was measured at $530 \mathrm{~nm}$ using a UV spectrophotometer (SHIMADZU, UV-2450, Dongguan HongCheng Optical Products Co. Ltd., Dongguan, China).

\subsection{Seed Treatment and Seedling Growth Conditions}

Two winter wheat cultivars with contrasting levels of salt stress tolerance were selected: Shimai and Xiaoyan60, herein referred to as "salt-sensitive" and "salt-tolerant", respectively. The cultivars were obtained from the Plant Genetics and Breeding Research Section, Center for Agricultural Resource Research (CARR). Xiaoyan60 was developed for tolerance to biotic and abiotic stresses [13]. Shimai is among the wheat cultivars widely cultivated in the North China Plain [53]. The seeds were surface sterilized in $70 \%$ ethanol for $10 \mathrm{~min}$ and $1 \% \mathrm{NaOCl}$ for $2 \mathrm{~min}$ and then washed four times with sterilized distilled water. Dry powder of the Trichoderma isolates was mixed with sterilized $1.5 \%$ xanthan gum gel following the procedure described previously [54,55]. We used a Trichoderma spore powder for seed coating that was easy to handle and enhanced the practical applicability at the farmer level. The seeds were coated with Th4 and Th6 at a rate of $10 \mathrm{~g}$ of fungal powder per $\mathrm{kg}$ of wheat seeds [56]. The Bacillus licheniformis C7 cell pellet was dissolved in approximately $30 \mathrm{~mL}$ of sterilized distilled water (OD660 $=0.6)$, and the suspension was added to sterilized $1.5 \%$ xanthan gum gel in a beaker. The inocula and the seeds were gently stirred into the xanthan gum mixture for 10 min using a stirring rod. The wet seeds were removed from the beaker and dried for $3 \mathrm{~h}$ on an aerated clean bench under aseptic conditions. In the control (without microbial coating), seeds were immersed in 1.5\% sterilized xanthan gum gel only with a similar procedure as that used for coating the seeds. The coated seeds were placed onto two layers of moistened filter paper in Petri plates. After one week, 30 (15 for each cultivar) uniformly emerged wheat seedlings were transferred to hydroponic vessels containing Hoagland solution under aerated conditions [57]. The seedlings were grown hydroponically for 14 days and exposed to either $0 \mathrm{mM} \mathrm{NaCl}$ or $200 \mathrm{mM} \mathrm{NaCl}$. In the $200 \mathrm{mM} \mathrm{NaCl}$ treatment, $4.38 \mathrm{~g}$ of NaCl was gradually added to the Hoagland nutrient solution once every two days to a final concentration of $200 \mathrm{mM} \mathrm{NaCl}$, whereas the same amount of Hoagland solution without $\mathrm{NaCl}$ was added to the $0 \mathrm{mM} \mathrm{NaCl}$-treated vessel. The growth room conditions were as follows: $21^{\circ} \mathrm{C}, 16$-h photoperiod, 
$400 \mu \mathrm{mol} \mathrm{m} \mathrm{m}^{-2} \mathrm{~s}^{-1}$ light intensity, and 55\% relative humidity. In this study, root colonization was confirmed following the described method in [58], with some modifications. Briefly, the root surfaces were sterilized in $1 \% \mathrm{NaOCl}$ for $2 \mathrm{~min}$ followed by rinsing with sterile distilled water. The root tissue was homogenized in sterilized mortar and pistil under aseptic conditions. The root homogenates belonging to the Trichoderma treatment were serially diluted and plated onto TSM, whereas those belonging to the Bacillus treatment were plated onto Luria-Bertani (LB) medium.

To evaluate the influence of the microbial seed treatment on the growth of wheat seedlings, the plant biomass weight, proline contents and photosynthetic parameters were measured after 11 days of seedling growth under salt stress treatment. The experiment was conducted for 32 days after sowing (seven days in Petri plates, 14 days in hydroponic, and 11 days in hydroponic conditions with $0 \mathrm{mM}$ $\mathrm{NaCl}$ or $200 \mathrm{mM} \mathrm{NaCl})$.

\subsection{Determination of Proline Contents}

The proline content was determined by using fully expanded leaves according to a method reported previously [59]. Briefly, freshly harvested leaves $(0.5 \mathrm{~g})$ of six plants per treatment were homogenized with $6 \mathrm{~mL}$ of $3 \%$ aqueous sulfosalicylic acid. After centrifugation, $2 \mathrm{~mL}$ of supernatant was mixed with $2 \mathrm{~mL}$ of ninhydrin reagent and $2 \mathrm{~mL}$ of glacial acetic acid, and then incubated in a $100^{\circ} \mathrm{C}$ boiling water bath for $1 \mathrm{~h}$. The proline content was measured at $520 \mathrm{~nm}$ using a UV-spectrophotometer (SHIMADZU, UV-2450) after extraction with $4 \mathrm{~mL}$ of toluene for $20 \mathrm{~min}$. Then, the proline content was determined using the calibration curve and expressed as $\mu$ mole proline $\mathrm{g}^{-1}$ fresh weight (FW).

\subsection{Photosynthetic Parameter Measurements}

Gas exchange measurements were conducted on the fully expanded third leaves (three plants) from each treatment using an LI-6400XT portable photosynthesis measurement system (Li-Cor Biosciences, Lincoln, NE, USA). Net photosynthesis $\left(A: \mu \mathrm{mol} \mathrm{CO} \mathrm{C}^{-2} \mathrm{~s}^{-1}\right)$, stomatal conductance $\left(g_{s}: \mathrm{mol} \mathrm{H}_{2} \mathrm{O} \mathrm{m}^{-2} \mathrm{~s}^{-1}\right)$, intercellular $\mathrm{CO}_{2}\left(C_{i}: \mu \mathrm{mol} \mathrm{CO} \mathrm{Cm}^{-2} \mathrm{~s}^{-1}\right)$, and transpiration rates $\left(E: \mathrm{mmol} \mathrm{H}_{2} \mathrm{O}\right.$ $\mathrm{m}^{-2} \mathrm{~s}^{-1}$ ) were measured at a photosynthetically active radiation (PAR) of $500 \mu \mathrm{mol}$ photon $\mathrm{m}^{-2} \mathrm{~s}^{-1}$, $400 \mu \mathrm{mol} \mathrm{CO} \mathrm{m}^{-2} \mathrm{~s}^{-1}$, with a $400 \mu \mathrm{mol} \mathrm{s}{ }^{-1}$ flow rate, at $40-60 \%$ humidity, and $27 \pm 2.5^{\circ} \mathrm{C}$. The water use efficiency $\left(W U E=\mathrm{A} / \mathrm{E}, \mu \mathrm{mol} \mathrm{CO} \mathrm{Cmol}^{-1} \mathrm{H}_{2} \mathrm{O}\right.$ ) was also calculated.

\subsection{Statistical Analysis}

An analysis of variance (ANOVA) was performed, followed by comparisons of the least squares means. F-tests were employed to evaluate the effects of cultivar (C), microbial treatment (M), salt stress (S), and their interactions. The above analysis was conducted with $\mathrm{R}$ software version 3.5 using the 'Car' [60] and 'lsmeans' [61] packages. All results given are means \pm standard errors (SE). Principal component analysis (PCA) was employed to verify the variation and compare the patterns induced as a result of the treatments.

\section{Results}

\subsection{Phylogenetic Analyses and Determination of Indole-3-Acetic Acid (IAA) Secretion}

In the current study, a total of eight Trichoderma isolates from the Tamarix chinensis rhizosphere and 12 Bacillus isolates from pig manure were isolated and screened for their IAA secretion abilities. Three IAA-producing strains (Th4, Th6 and C7) were selected for further analysis. The C7 isolate secreted a significantly $(p<0.05)$ higher amount of IAA under $200 \mathrm{mM} \mathrm{NaCl}$ treatment than under $0 \mathrm{mM}$ treatment. Compared with C7, fungal isolates Th4 and Th6 produced dramatically lower levels of IAA (Table 1). 
Table 1. Indole-3-acetic acid (IAA) secretion $\left(\mu \mathrm{g} \mathrm{mL}^{-1}\right)$ potential of $\mathrm{C} 7$, Th4, and Th6 isolates under nonstress $(0 \mathrm{mM})$ and salt stress $(200 \mathrm{mM})$.

\begin{tabular}{ccc}
\hline Isolates & \multicolumn{2}{c}{ Salt stress $\mathbf{( N a C l )}$} \\
\hline & $\mathbf{0 ~} \mathbf{~} \mathbf{M}$ & $\mathbf{2 0 0} \mathbf{~} \mathbf{M}$ \\
\hline $\mathrm{C} 7$ & $1.03 \pm 0.02 \mathrm{~b}$ & $1.18 \pm 0.02 \mathrm{c}$ \\
$\mathrm{Th} 4$ & $0.11 \pm 0.020 \mathrm{a}$ & $0.11 \pm 0.02 \mathrm{a}$ \\
$\mathrm{Th} 6$ & $0.09 \pm 0.02 \mathrm{a}$ & $0.05 \pm 0.02 \mathrm{a}$
\end{tabular}

The values are the means of three replicates \pm standard error (SE) $(n=3)$. Different letters denote significant differences between treatments after Tukey-adjusted comparisons $(p<0.05)$.

Fungal and bacterial isolates were identified by sequencing their internal transcribed spacer (ITS) and 16S rRNA genes, respectively. The Th4, Th6 and C7 isolate nucleotide sequences were subjected to basic alignment local tool (BLAST) analysis against the National Center for Biotechnology (NCBI) database. Phylogenetic analysis based on ITS showed that the Th4 and Th6 isolates had a close relationship with Trichoderma yunnanense and Trichoderma afroharzianum, respectively (Figure 1A). Likewise, the phylogenetic analysis based on 16S rRNA showed that the C7 isolate showed the highest similarity with Bacillus licheniformis (Figure 1B). The nucleotide sequences of Th4, Th6, and C7 isolates have been deposited in the NCBI under accession numbers MT762351.1, MT762352.1, and MT762371.1, respectively.

$\mathbf{A}$

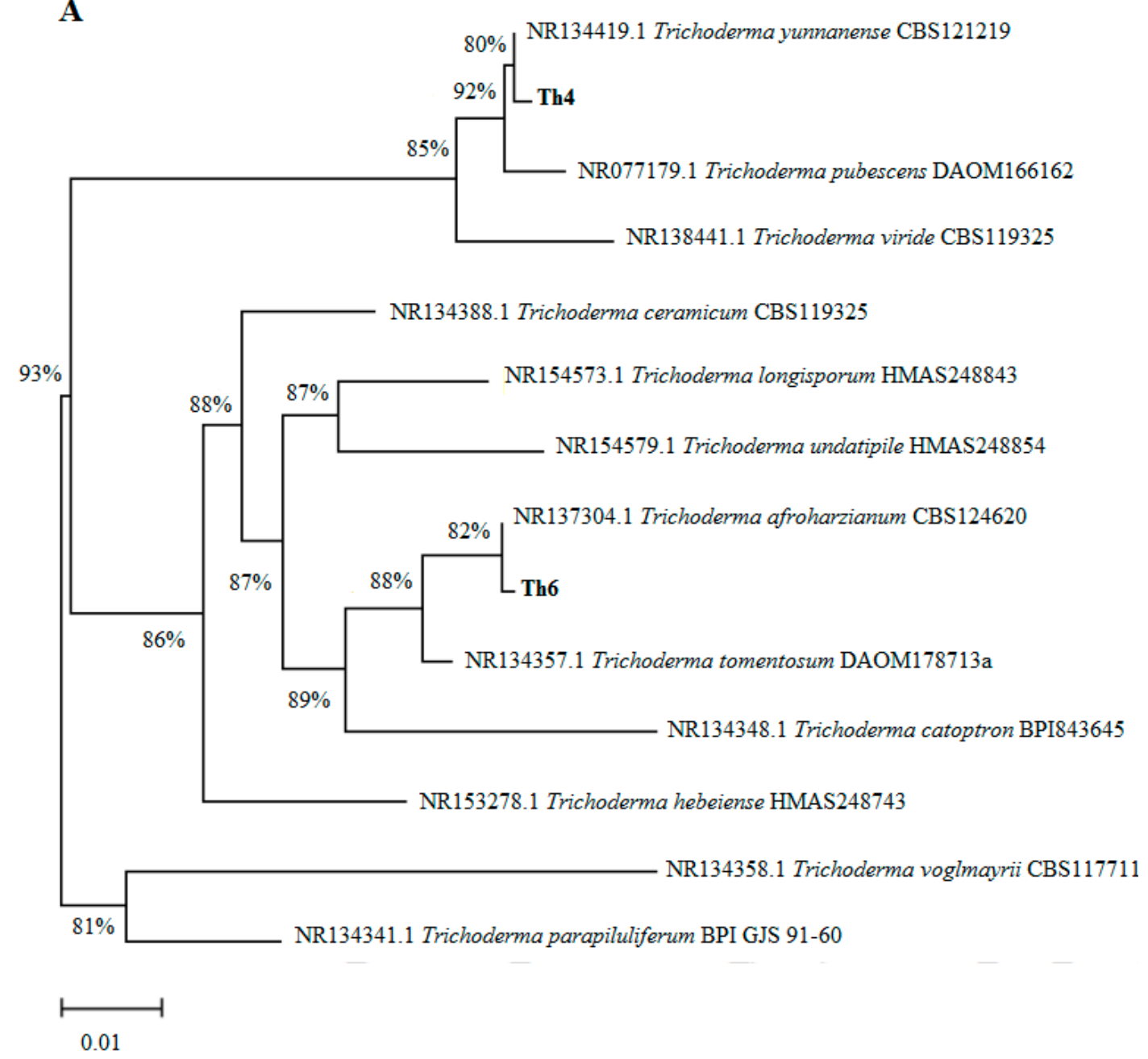

Figure 1. Cont. 


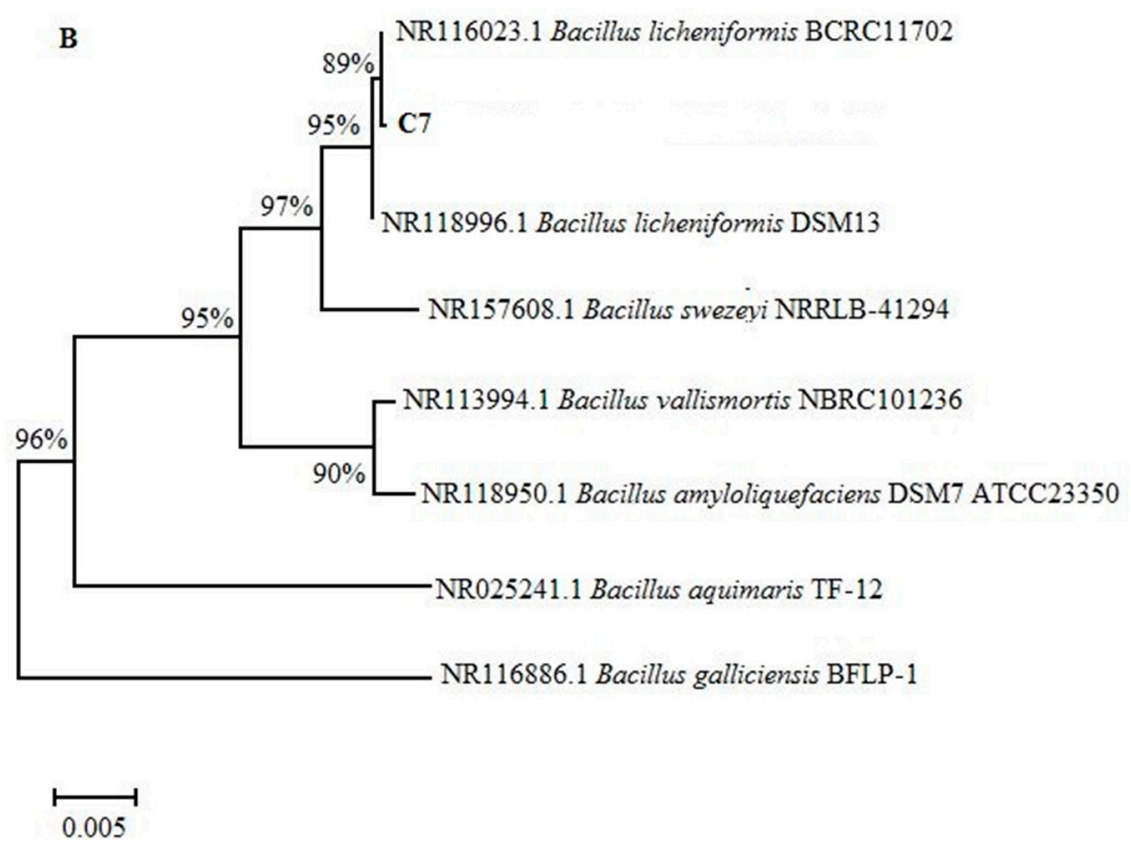

Figure 1. Phylogenetic tree showing the relationship among (A) Th4 and Th6 based on sequencing results of the ITS region and (B) C7 based on sequence results of the 16S rRNA gene.

\subsection{Proline Contents}

The effects of cultivar (C), microbial seed treatment (M), and salt stress $(\mathrm{S})$ on the proline content were assessed (Table 2). Under unstressed conditions $(0 \mathrm{mM} \mathrm{NaCl})$, no significant difference in the proline content was noted between the uncoated and the three seed-coating treatments of cultivar Shimai, while a significant decrease in proline contents with the seed-coating treatments was observed for Xiaoyan60. In the treatments with salt stress $(200 \mathrm{mM} \mathrm{NaCl})$, a significantly lower proline content was observed in the three seed-coating treatments than in the uncoated treatment of cultivar Shimai; for cultivar Xiaoyan60, the $\mathrm{C} 7$ coating treatment increased the proline content to a level higher than that of the uncoated treatment, while the Th4 and Th6 coating treatments yielded lower proline contents than the uncoated treatment. The three factors $(\mathrm{C}, \mathrm{M}$, and $\mathrm{S})$ all showed significant effects on the proline content (Table 2B).

\subsection{Photosynthetic Parameters}

Photosynthetic parameters, including net photosynthesis $(A)$, stomatal conductance $\left(g_{s}\right)$, intercellular $\mathrm{CO}_{2}\left(C_{i}\right)$, transpiration $(E)$ and water use efficiency (WUE), were measured to understand the influence of cultivar, microbial seed treatment, and salt stress on photosynthetic parameters in wheat seedlings. The net photosynthesis $(A)$ with the control and $C 7$ treatments decreased under salt stress treatment. However, seedlings of both cultivars had relatively elevated $A$ when the seeds were coated with Th4 and Th6 (Figure 2A). Further analysis revealed that $A$ was significantly $(p<0.05)$ correlated with salt stress, microbial strain, and their interactive effects but not with the interactive effects of all three main factors $(\mathrm{C} \times \mathrm{S} \times \mathrm{M})$ (Table 3$)$. The influence of salt stress on stomatal conductance $\left(g_{s}\right)$ was significant $(p<0.001$, Table 3$)$. Under nonstress conditions, seedlings grown from coated seeds exhibited nonsignificant lower stomatal conductance than control plants. Except for the interaction between microbial seed treatment $x$ salt stress $(\mathrm{M} \times \mathrm{S})$, none of the interactions of the main effects were significant (Table 3). 
Table 2. Leaf proline contents ( $\mu \mathrm{mol}$ proline $\mathrm{g}^{-1} \mathrm{FW}$ ) of wheat cultivars (Shimai and Xiaoyan60) under microbial seed treatment and salt stress.

\begin{tabular}{|c|c|c|c|}
\hline \multicolumn{4}{|c|}{$\mathbf{A}$} \\
\hline \multirow{2}{*}{ Cultivars } & \multirow{2}{*}{ Seed Treatment } & \multicolumn{2}{|c|}{$\mu \mathrm{mol}$ Proline $\mathrm{g}^{-1} \mathrm{FW}$} \\
\hline & & $0 \mathrm{mM} \mathrm{NaCl}$ & $200 \mathrm{mM} \mathrm{NaCl}$ \\
\hline \multirow{4}{*}{ Shimai } & Uncoated & $2.16 \pm 1.24 \mathrm{a}$ & $67.98 \pm 1.24 \mathrm{e}$ \\
\hline & C7 & $0.97 \pm 1.24 \mathrm{a}$ & $56.38 \pm 1.24 \mathrm{~d}$ \\
\hline & Th4 & $2.67 \pm 1.24 \mathrm{a}$ & $59.23 \pm 1.24 \mathrm{~d}$ \\
\hline & Th6 & $1.59 \pm 1.24 \mathrm{a}$ & $61.09 \pm 1.24 \mathrm{~d}$ \\
\hline \multirow[t]{4}{*}{ Xiaoyan60 } & Uncoated & $12.76 \pm 1.24 b$ & $28.07 \pm 1.24 c$ \\
\hline & C7 & $0.55 \pm 1.24 \mathrm{a}$ & $69.18 \pm 1.24 \mathrm{e}$ \\
\hline & Th4 & $1.50 \pm 1.24 \mathrm{a}$ & $17.20 \pm 1.24 b$ \\
\hline & Th6 & $1.28 \pm 1.24 \mathrm{a}$ & $3.50 \pm 1.24 \mathrm{a}$ \\
\hline \multicolumn{4}{|c|}{ B } \\
\hline \multicolumn{2}{|c|}{ Treatments } & \multicolumn{2}{|c|}{$F$} \\
\hline \multicolumn{2}{|c|}{ C } & \multicolumn{2}{|c|}{$560.93^{* * *}$} \\
\hline \multicolumn{2}{|c|}{ M } & \multicolumn{2}{|c|}{$122.04^{* * *}$} \\
\hline \multicolumn{2}{|c|}{ S } & \multicolumn{2}{|c|}{$4666.77^{* * *}$} \\
\hline \multicolumn{2}{|c|}{$\mathrm{C} \times \mathrm{M}$} & \multicolumn{2}{|c|}{$149.81^{* * *}$} \\
\hline \multicolumn{2}{|c|}{$\mathrm{C} \times \mathrm{S}$} & \multicolumn{2}{|c|}{$739.18^{* * *}$} \\
\hline \multicolumn{2}{|c|}{$\mathrm{M} \times \mathrm{S}$} & \multicolumn{2}{|c|}{$122.49^{* * *}$} \\
\hline \multicolumn{2}{|c|}{$\mathrm{C} \times \mathrm{M} \times \mathrm{S}$} & \multicolumn{2}{|c|}{$168.61^{* *}$} \\
\hline
\end{tabular}

(A) The values are the means of six replicates $\pm \mathrm{SE}(n=6)$. Different letters denote a significant difference between treatments after Tukey's HSD test $(p<0.05)$. (B) Three factorial ANOVA results for proline content in the two wheat cultivars $(C)$ under microbial treatments $(M)$, salt stress $(S)$, and their interaction $(C \times M, C \times S, M \times S$ and $\mathrm{C} \times \mathrm{M} \times \mathrm{S}) .{ }^{* *}$ and ${ }^{* * *}$ denotes that the mean difference is significant at the $p<0.01$, and $p<0.001$ levels, respectively.

Table 3. Photosynthetic parameters of two wheat cultivars (C) in response to microbial treatment (M), salt stress (S), and their interaction.

\begin{tabular}{cccccc}
\hline \multirow{2}{*}{ Treatment } & \multicolumn{5}{c}{ Photosynthetic Parameters } \\
\cline { 2 - 6 } & $A$ & $g_{s}$ & $C_{i}$ & $E$ & WUE \\
\hline $\mathrm{C}$ & $0.60 n s$ & $2.64 n s$ & $0.00 n s$ & $1.67 n s$ & $10.43^{* *}$ \\
$\mathrm{M}$ & $25.29^{* * *}$ & $2.65 n s$ & $18.69^{* * *}$ & $6.53^{* *}$ & $73.30^{* * *}$ \\
$\mathrm{~S}$ & $258.58^{* * *}$ & $117.77^{* * *}$ & $0.00 n s$ & $138.18^{* * *}$ & $9.66^{* *}$ \\
$\mathrm{C} \times \mathrm{M}$ & $8.36^{* * *}$ & $1.67 n s$ & $3.54^{*}$ & $0.39 n s$ & $1.97 n s$ \\
$\mathrm{C} \times \mathrm{S}$ & $4.42^{*}$ & $2.90 n s$ & $1.46 n s$ & $2.14 n s$ & $1.23 n s$ \\
$\mathrm{M} \times \mathrm{S}$ & $13.63^{* * *}$ & $2.92^{*}$ & $8.17^{* * *}$ & $6.41^{* *}$ & $22.59^{* * *}$ \\
$\mathrm{C} \times \mathrm{M} \times \mathrm{S}$ & $2.18 n s$ & $2.04 n s$ & $1.39 n s$ & $0.78 n s$ & $2.42 n s$ \\
\hline
\end{tabular}

The values in the table represent three factorial ANOVA results for the photosynthetic parameters: net photosynthesis $(A)$, stomatal conductance $\left(g_{s}\right)$, intercellular $\mathrm{CO}_{2}\left(C_{i}\right)$, transpiration $(E)$, and water use efficiency (WUE) under microbial treatment $(M)$, salt stress $(S)$, cultivar $(C)$ and their interaction $(C \times M, C \times S, M \times S$ and $C \times M \times S)$. ***, ***, and $n s$ denotes that the mean difference is significant at the $p<0.05, p<0.01, p<0.001$ and non-significant levels, respectively.

The influence of seed treatment with different microbial strains $(\mathrm{M})$ on intercellular $\mathrm{CO}_{2}(\mathrm{Ci})$ was significant ( $p<0.001$, Table 3). The Ci was higher in the control and C7-coated seedlings than in the Th4 and Th6 seedlings (Figure 2C) regardless of cultivar and salt stress exposure. Microbial seed treatment $\times$ salt stress $(\mathrm{M} \times \mathrm{S})$ and cultivar $\times$ microbial seed treatment $(\mathrm{C} \times \mathrm{M})$ interactions were significantly correlated with intercellular $\mathrm{CO}_{2}(p<0.001 ; p<0.05$, respectively, Table 3).

Both salt stress and microbial strain significantly $(p<0.05)$ influenced the leaf transpiration rate $(E)$. The seedlings grown from Th4 and Th6 exhibited consistently lower $\mathrm{E}$ than control plants irrespective of cultivar or salt stress (Figure 2D). The microbial seed treatment $x$ salt stress $(\mathrm{M} \times \mathrm{S})$ interaction was significantly $(p<0.01)$ different for $E$ (Table 3). 


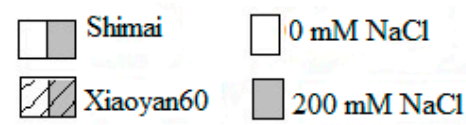

A

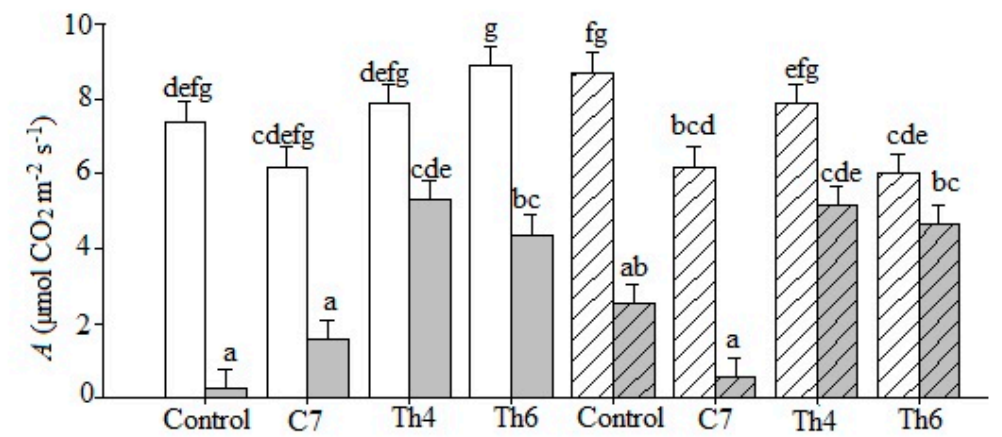

B

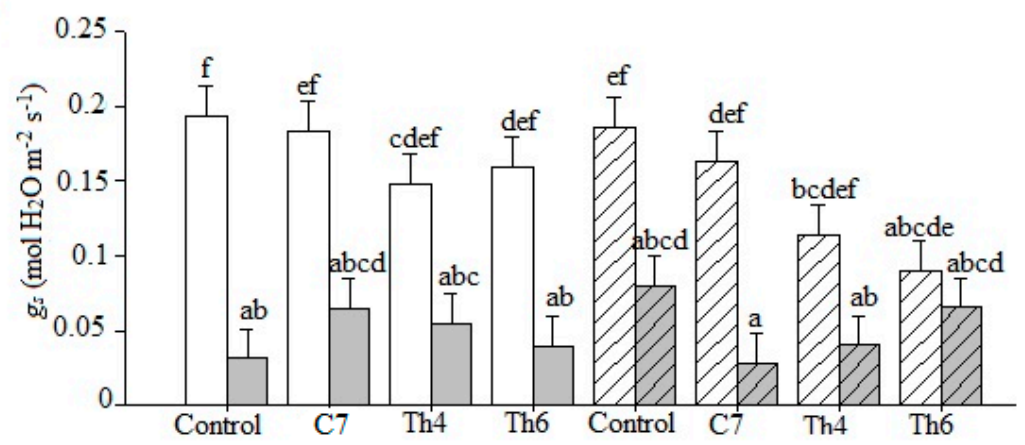

C
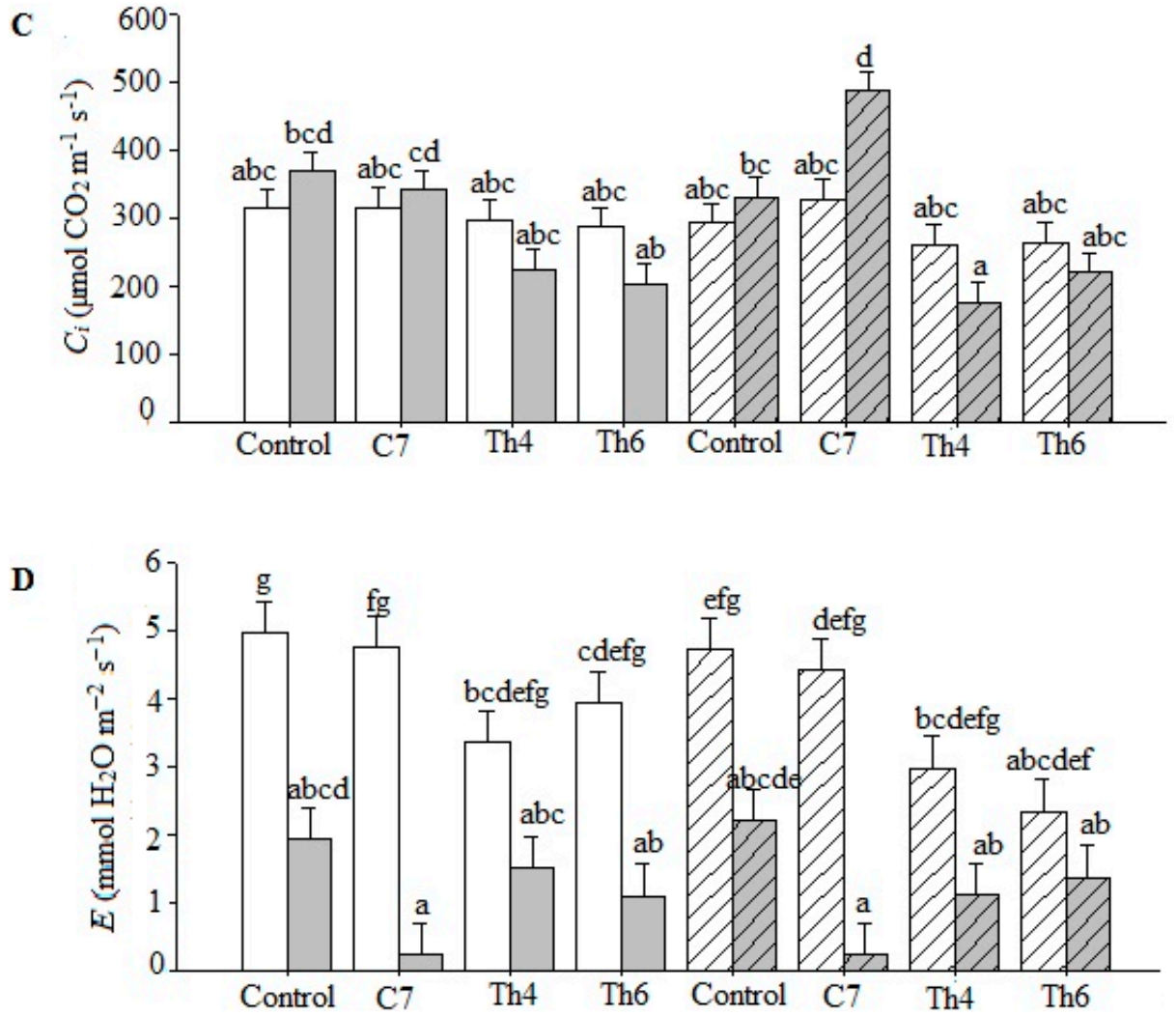

Figure 2. Cont. 


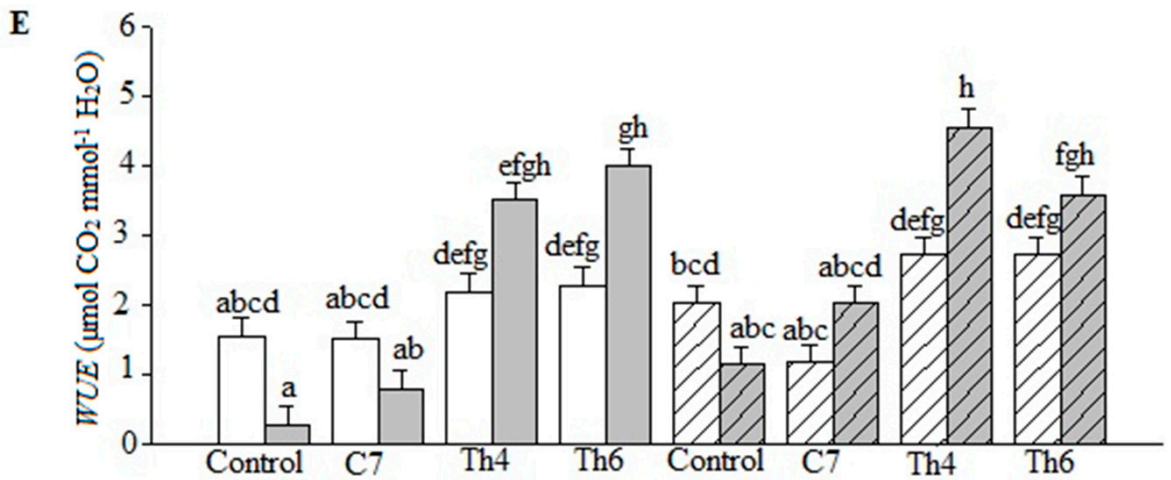

Figure 2. Photosynthetic parameters of wheat cultivars Shimai and Xiaoyan60 under the microbe and salt stress treatments. Control, C7, Th4, and Th6 represent uncoated seeds, C7 seed coating, Th4 seed coating, and Th6 seed coating, respectively. The salt stress levels were $0 \mathrm{mM} \mathrm{NaCl}$ and $200 \mathrm{mM} \mathrm{NaCl}$. The values are the means of three replicates \pm SE $(n=3)$. (A) Net photosynthesis $(A),(\mathbf{B})$ stomatal conductance $\left(g_{s}\right),(\mathbf{C})$ intercellular $\mathrm{CO}_{2}\left(\mathrm{C}_{i}\right),(\mathbf{D})$ transpiration $(E)$, and (E) water use efficiency (WUE). The wheat cultivars: Shimai in white-gray bars and Xiaoyan60 in white-gray bars with course pattern. Different letters denote significant differences between the treatments and the cultivars according to Tukey-adjusted comparisons $(p<0.05)$. Means sharing a letter are not significantly different.

The leaf WUE was significantly $(p<0.01$ ) correlated with all main factors (cultivar, microbial strain, and salt stress), with an interactive effect of microbial strains and salt stress (Table 3 ). Under stress conditions, WUE was found to be higher in seedlings grown from Th4 and Th6 irrespective of cultivar (Figure 2E).

Under unstressed conditions, microbial isolates increased the seedling biomass of both cultivars compared to the control treatment. Salt stress treatment severely reduced the biomass; however, microbial seed treatment, particularly Trichoderma isolates, improved the shoot and root biomass weight (Figure 3 and Table 4).

Table 4. Plant biomass production for the two wheat cultivars (C) in response to microbial treatment (M) and salt stress (S).

\begin{tabular}{ccc}
\hline \multirow{2}{*}{ Treatments } & \multicolumn{2}{c}{$F$} \\
\cline { 2 - 3 } & Shoot & Root \\
\hline $\mathrm{C}$ & $50.391^{* * *}$ & $228.01^{* * * *}$ \\
$\mathrm{M}$ & $69.13^{* * *}$ & $65.31^{* * *}$ \\
$\mathrm{~S}$ & $666.32^{* * *}$ & $846.81^{* * *}$ \\
$\mathrm{C} \times \mathrm{M}$ & $6.40^{* *}$ & $5.47^{* *}$ \\
$\mathrm{C} \times \mathrm{S}$ & $11.35^{* *}$ & $141.61^{* * *}$ \\
$\mathrm{M} \times \mathrm{S}$ & $1.33^{n s}$ & $3.47^{*}$ \\
$\mathrm{C} \times \mathrm{M} \times \mathrm{S}$ & $7.05^{* * *}$ & $14.43^{* * *}$
\end{tabular}

The values in the table represent analysis of variance (ANOVA) test for biomass of the wheat cultivars (C) under microbial treatment $(\mathrm{M})$, salt stress (S), and their interaction $(\mathrm{C} \times \mathrm{M}, \mathrm{C} \times \mathrm{S}, \mathrm{M} \times \mathrm{S}$ and $\mathrm{C} \times \mathrm{M} \times \mathrm{S}) .{ }^{*}, * *$, $* * *$, and $n s$ denotes that the mean difference is significant at the $p<0.05, p<0.01, p<0.001$ and nonsignificant levels, respectively. 

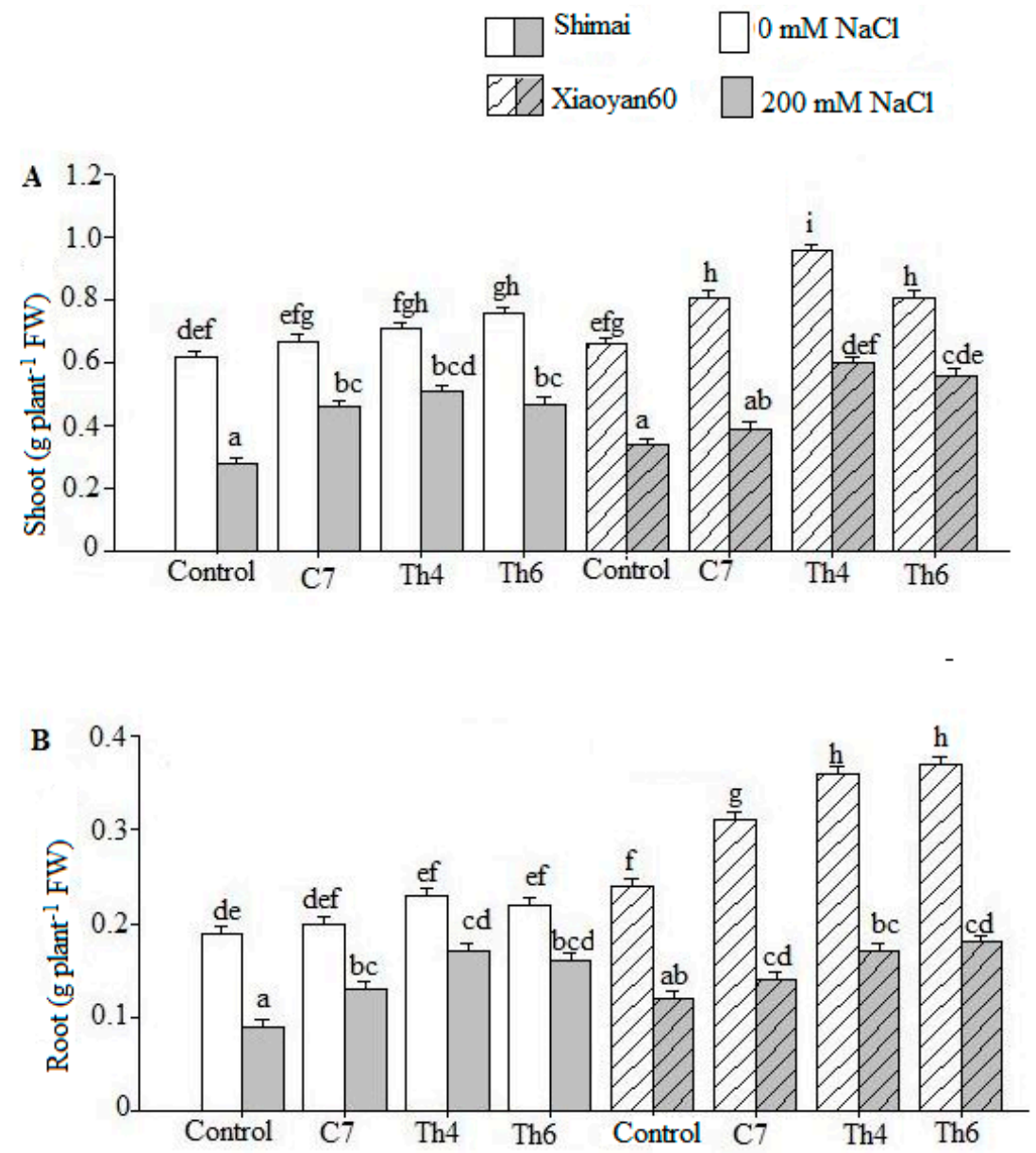

Figure 3. Biomass production of Shimai and Xiaoyan60 under microbe and salt stress treatments. Control, C7, Th4, and Th6 represent uncoated seeds, C7 seed coating, Th4 seed coating, and Th6 seed coating, respectively. The plant was harvested from the hydroponic vessel at the end of the experiment (32 days after sowing). The shoot (A) and root (B) fresh samples were wiped dry using soft paper towel, and the fresh weight was recorded immediately. The values are the means of three replicates \pm SE, $(n=3)$. The wheat cultivars: Shimai in white-gray bars and Xiaoyan60 in white-gray bars with course pattern. Different letters denote significant differences between the treatments and the cultivars according to Tukey-adjusted comparisons $(p<0.05)$. Means sharing a letter are not significantly different.

\subsection{Principal Component Analysis of Cultivar-Specific Photosynthetic Parameters}

Figure 4 shows the PCA of the photosynthetic parameters $\left(A, g_{s}, C_{i}, E\right.$, and WUE) for both cultivars. PC1 and PC2 accounted for $53.6 \%$ and $44.5 \%$ of the total variation, respectively, for Shimai (Figure $4 \mathrm{~A}$ ). A similar pattern of total variation (54.6\% and 38.8\%) was explained in Xiaoyan60 by PCA1 and PC2 (Figure 4B), respectively. In the treatments without salt stress, limited separation was exhibited between seedlings with seed coating treatments and control plants. In the salt stress treatments, seedlings were separated by the microbial strain used for seed treatment for both cultivars except that an overlap was noted for Xiaoyan60 coated with Th6 and Th4. In general, microbial seed coating and salt stress caused strong variation in the photosynthetic parameters in both studied cultivars. 


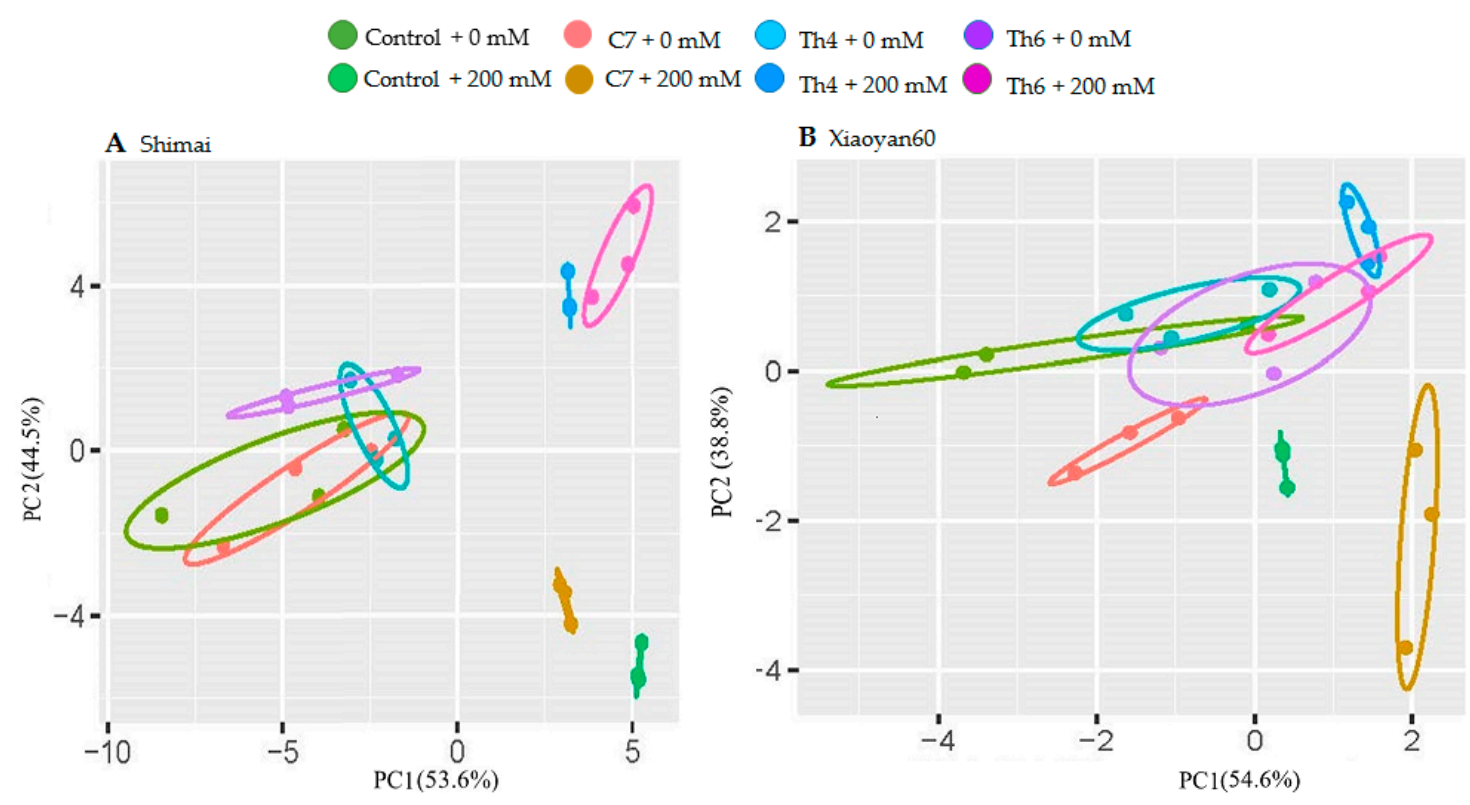

Figure 4. Results of two-dimensional principal component analysis (PCA) for photosynthetic gas exchange parameters in two wheat cultivars: (A) Shimai and (B) Xiaoyan60. Control $+0 \mathrm{mM}$ and control $+200 \mathrm{mM}$ are combinations of uncoated seed with 0 and $200 \mathrm{mM} \mathrm{NaCl}$, respectively. $\mathrm{C} 7+0 \mathrm{mM}$, Th4 + $0 \mathrm{mM}$, Th6 + $0 \mathrm{mM}, \mathrm{C} 7+200 \mathrm{mM}$, Th4 +200 mM and Th6 +200 mM are combinations of seed coating treatments with C7, Th4, and Th6 under 0 and $200 \mathrm{mM} \mathrm{NaCl}$, respectively.

\section{Discussion}

Maintaining endogenous concentrations of phytohormones using the seed priming technique was shown to have a positive impact on salt stress resistance in wheat $[62,63]$. The utilization of PGPM to enhance wheat tolerance against salt stress has been considered an important eco-sustainable approach [15]. Bacillus produced high amounts of IAA compared to Trichoderma isolates. However, the production of high IAA was not correlated with plant growth in a Bacillus treatment. When used in seed treatment, beneficial root-colonizing microbes that secrete IAA can potentially manipulate the plant's endogenous pool of IAA, contributing to host tolerance to the harmful effects of environmental stress $[64,65]$. However, the amount of microbial IAA required by the host may vary within an extremely narrow range based on plant phenotype; as a result, the plant-microbe interaction outcomes are sometimes diverse and highly dependent on the respective species [66,67]. Comprehensive studies are necessary to identify the level of IAA required for plant growth in a specific microenvironment.

In previous studies, increased accumulation of proline in leaf, root, and stem tissues was reported as a common response to salt stress in Jerusalem artichoke [68] and Kosteletzkya virginica L. [69]. The accumulation of proline under abiotic stress is associated with the plant response to protect against damage to the cellular machinery [70]. In contrast, decreased proline content was also reported in previous studies; for instance, inoculation of Rhizobacteria onto Arachis hypogaea L. resulted in a low plant proline content under $100 \mathrm{mM}$ salt stress [71]. In our study, leaf proline accumulation declined in the treatments with Th4 and Th6 in the presence of salt stress. The decreased proline level is unlikely to be a direct downregulation by microbes since it is perceived that abundant proline accumulation in the cytoplasm is one strategy employed by plants to cope with environmental stresses [26]. One plausible explanation for this phenomenon is that microbes induced a decrease in osmotic stress to plants through some yet unknown mechanisms, which in turn induced a downregulation of proline production in plants. It should also be noted that other factors could also influence the level of proline in plants since proline also plays roles other than counteracting the effects of osmotic stress [72]. This suggests that the mechanisms underlying the decreased proline content in the fungal treatments under salt stress are complex and need further investigation. 
Salt stress restricts plant biomass accumulation by causing irreversible damage to the photosynthetic machinery [73], which in turn affects photosynthetic gas exchange parameters. However, the application of PGPM counteracts the deleterious effect of salt stress [74]. Likewise, certain Trichoderma species are known to enhance photosynthetic efficiency under salt stress [75]. Our results also demonstrated that the net photosynthesis rate of plants grown from noncoated (control) and Bacillus-coated seeds decreased under salt stress, but plants grown from seeds coated with Trichoderma isolates showed substantial biomass improvement in this regard. This finding is also consistent with a previous report [76] in which the colonization of Trichoderma virens improved the photosynthetic rate. The improvement in Trichoderma-colonized plants is potentially explained by the stimulation of carbon sink activity through root exudates, therefore manipulating the photosynthesis rate in the leaves $[75,76]$. Our results revealed that the photosynthesis rates in plants grown from seeds coated with Bacillus were unambiguously decreased under salt stress exposure. However, $[77,78]$ claimed that the inoculation of Bacillus strains onto pepper and radish improved net photosynthesis under salt stress. Coupled with the improvement of net photosynthesis, the findings of the current experiment also revealed that wheat grown from seeds coated with Trichoderma had lower stomatal conductance, intercellular $\mathrm{CO}_{2}$, transpiration, and higher water use efficiency under salt stress. Moreover, our results showed that WUE was reduced under salt stress treatment with the uncoated treatments of both cultivars. However, plants grown from seeds coated with Trichoderma isolates showed significantly elevated WUE, suggesting that the fungal isolates dramatically improved water use efficiency compared to the bacterial isolate and control. Although the mechanisms were not investigated in this study, recent findings reported the effect of Trichoderma inoculation onto Arabidopsis and shed some light on the regulation of stomatal aperture and transpiration [79], thereby reducing water loss and improving the regulation of water use efficiency.

Proline is primarily synthesized in the photosynthetic apparatus, and the highest accumulation was found in the chlorophyll of leaves [80]. The optimum degree of proline accumulation appears to be an essential response to a variety of abiotic stresses [81]. In this study, proline synthesis increased with salt stress in both cultivars, although the level of accumulation varied. A positive association was detected between proline accumulation and photosynthetic parameters in Trichoderma treatments under salt stress (Table 2 and Figure 2). The photosynthetic performance of wheat plants in the control and Bacillus treatments was low under salt stress, even though a high concentration of proline accumulated in the leaves of these plants. Although extensive research has been performed regarding proline metabolism in plants, further study is imperative to explore the discrepancies and metabolic implications of plant-microbe interactions.

Furthermore, the formulations containing Trichoderma conidia enhanced crop growth and abiotic stress tolerance as reviewed previously [82]. As mentioned above, Trichoderma seed coating strongly influenced proline contents, improved net photosynthesis and water use efficiency, and improved plant biomass under salt stress. This profound benefit suggests the possibility that the studied Trichoderma isolates could be considered as a plant biostimulant for amelioration of wheat seedling growth in saline soil. Previous studies reported that formulations containing certain Trichoderma species increased abiotic stress tolerance [83], increased nutrient uptake and boosted stress response [82], improved the nutrient uptake and yield of leafy vegetables [84], plant physiology and yield [85], and is regarded as a plant biostimulant.

\section{Conclusions}

Two fungal strains, Th4 and Th6, and one bacterial strain, C7, were isolated from saline soil and pig manure, respectively. Phylogenetic analyses showed that they are closely related to Trichoderma yunnanense, Trichoderma afroharzianum, and Bacillus licheniformis. The three isolates all demonstrated the ability to produce IAA under salt-stressed conditions. Microbial seed coating was performed with salt-sensitive (Shimai) and salt-tolerant (Xiaoyan60) wheat cultivars. The leaf proline content dramatically increased under salt stress for both cultivars. Under salt stress, Th4 and Th6- treated 
plants showed lower leaf proline contents compared with the uncoated treatments for both cultivars. Trichoderma treatments substantially improved the net photosynthetic rate, water use efficiency, and plant biomass under salt-stressed conditions.

Author Contributions: Conceptualization, B.L.; data curation, A.M.O., T.H. and T.R.W.; formal analysis, A.M.O., T.R.W. and H.Z.; investigation, A.M.O. and B.L.; methodology, A.M.O. and T.H.; resources, H.S., X.L. and X.W.; software, T.H.; supervision, B.L.; visualization, H.Z.; writing-original draft, A.M.O. and H.Z.; writing-review and editing, A.M.O., T.R.W. and B.L. All authors have read and agreed to the published version of the manuscript.

Funding: This work was supported by the Strategic Priority Research Program of the Chinese Academy of Sciences (XDB40020204), the National Natural Science Foundation of China $(41930865,41807058,31861133018)$, and the National Key Research and Development Program of China (2018YFD0800306).

Acknowledgments: We acknowledge financial support from the CAS-TWAS President's Fellowship for International Doctoral Students.

Conflicts of Interest: The authors declare no conflict of interest. The funders had no role in the design of the study; in the collection, analyses, or interpretation of data; in the writing of the manuscript; or in the decision to publish the results.

\section{References}

1. Isayenkov, S.V.; Maathus, F. Plant salinity stress: Many unanswered questions remain. Front. Plant. Sci. 2017, 10, 80. [CrossRef]

2. Ivushkin, K.; Bartholomeus, H.; Bregt, A.K.; Pulatov, A.; Kempen, B.; de Sousa, L. Global mapping of soil salinity change. Remote Sens. Environ. 2019, 231, 111260. [CrossRef]

3. Wang, W.; Vinocur, B.; Altman, A. Plant responses to drought, salinity, and extreme temperatures: Toward genetic engineering for stress tolerance. Planta 2003, 218, 1-14. [CrossRef] [PubMed]

4. Acosta-Motos, J.; Ortuño, M.; Bernal-Vicente, A.; Diaz-Vivancos, P.; Sanchez-Blanco, M.; Hernandez, J.A. Plant Responses to Salt Stress: Adaptive Mechanisms. Agronomy 2017, 7, 18. [CrossRef]

5. Liu, F.; Mo, X.; Zhang, S.; Chen, F.; Li, D. Gas exchange characteristics and their influencing factors for halophytic plant communities on west coast of Bohai Sea. PLoS ONE 2020, 15, e0229047. [CrossRef] [PubMed]

6. Morales, F.; Ancín, M.; Fakhet, D.; González-Torralba, J.; Gámez, A.L.; Seminario, A.; Soba, D.; Ben Mariem, S.; Garriga, M.; Aranjuelo, I. Photosynthetic Metabolism under Stressful Growth Conditions as a Bases for Crop Breeding and Yield Improvement. Plants 2020, 9, 88. [CrossRef] [PubMed]

7. Flexas, J.; Niinemets, U.; Gallé, A.; Barbour, M.M.; Centritto, M.; Diaz-Espejo, A.; Douthe, C.; Galmés, J.; Ribas-Carbo, M.; Rodriguez, P.L.; et al. Diffusional conductance to $\mathrm{CO}_{2}$ as a target for increasing photosynthesis and photosynthetic water use efficiency. Photosyn. Res. 2013, 117, 45-59. [CrossRef]

8. Medrano, H.; Tomás, M.; Martorell, S.; Flexas, J.; Hernández, H.; Rosselló, J.; Pou, A.; Escalona, J.M.; Bota, J. From leaf to whole-plant water use efficiency (WUE) in complex canopies: Limitations of leaf WUE as a selection target. Crop. J. 2015, 3, 220-228. [CrossRef]

9. Shabala, L.; Mackay, A.; Tian, Y.; Jacobsen, S.E.; Zhou, D.; Shabala, S. Oxidative stress protection and stomatal patterning as components of salinity tolerance mechanism in quinoa (Chenopodium quinoa). Physiol. Plant. 2012, 146, 26-38. [CrossRef]

10. Bhuiyan, M.S.I.; Mynard, G.; Raman, A.; Hodgkins, D.; Mitchell, D.; Nicol, H. Salt effects on proline and glycine betaine levels and photosynthetic performance in Melilptus Siculus, Tecticorni pergranulata and Thinopyrum ponticum measured in simulated saline conditions. Funct Plant Biol. 2016, 43, 254. [CrossRef]

11. Renzhao, M.; Fitzpatrick, R.W.; Xiaojing, L.; Davis, P.J. Chemical properties of selected soils from the North China Plain. In Regional Water and Soil Assessment for Managing Sustainable Agriculture in China and Australia; McVicar, T.R., Li, R., Walker, J., Fizpatrick, R.W., Liu, C., Eds.; ACIAR Monograph: Canberra, Australia, 2002; Volume 84, pp. 173-186.

12. Li, J.; Pu, L.; Han, M.; Zhu, M.; Zhang, R.; Xiang, Y. Soil salinization research in China: Advances and prospects. J. Geogr. Sci. 2014, 24, 943-960. [CrossRef]

13. Li, Z.S.; Zheng, Q.; Li, H. Review and new progress in wheat wide hybridization for improving the resistance to biotic and abiotic stresses. In Advances in Wheat Genetics: From Genome to Field; Ogihara, Y., Takumi, S., Hand, H., Eds.; Springer: Tokyo, Japan, 2015. [CrossRef] 
14. Wille, L.; Messmer, M.M.; Studer, B.; Hohmann, P. Insights to plant-microbe interactions provide opportunities to improve resistance breeding against root diseases in grain legumes. Plant. Cell Environ. 2018, 42, $20-40$. [CrossRef] [PubMed]

15. Miransari, M.; Smith, D. Sustainable wheat (Triticum aestivum L.) production in saline fields: A review. Crit. Rev. Biotechnol. 2019, 39, 999-1014. [CrossRef] [PubMed]

16. Mitter, B.; Brader, G.; Pfaffenbichler, N.; Sessitsch, A. Next-generation microbiome applications for crop production-limitations and the need of knowledge-based solutions. Curr. Opin. Microbiol. 2019, 49, 59-65. [CrossRef] [PubMed]

17. Dodd, I.C.; Perez-Alfocea, F. Microbial amelioration of crop salinity stress. J. Exp. Bot. 2012, 63, 3415-3428. [CrossRef]

18. Pandey, A.; Tripathi, A.; Srivastava, P.; Choudhary, K.K.; Dikshit, A. Plant growth-promoting microorganisms in sustainable agriculture. In Role of Plant. Growth Promoting Microorganisms in Sustainable Agriculture and Nanotechnology; Ajay, K., Amit, K., Singh, K., Kumar, C., Eds.; Woodhead Publishing: Cambridge, UK, 2019; pp. 1-19. [CrossRef]

19. Zhang, S.; Gan, Y.; Xu, B. Application of Plant-Growth-Promoting Fungi Trichoderma longibrachiatum T6 enhances tolerance of wheat to salt stress through improvement of antioxidative defense system and gene expression. Front. Plant. Sci. 2016, 7, 1-11. [CrossRef]

20. Zhang, S.; Xu, B.; Gan, Y. Seed treatment with Trichoderma longibrachiatum T6 promotes wheat seedling growth under $\mathrm{NaCl}$ stress through activating the enzymatic and non-enzymatic antioxidant defense systems. Int. J. Mol. Sci. 2019, 20, 3729. [CrossRef]

21. Ahmad, P.; Hashem, A.; Elsayed, F.A.; Alqarawi, A.A.; John, R.; Egamberdieva, D.; Gucel, S. Role of Trichoderma harzianum in mitigating $\mathrm{NaCl}$ stress in Indian mustard (Brassica juncea L.) through antioxidative defense system. Front. Plant. Sci. 2015, 6, 1-15. [CrossRef]

22. Singh, R.P.; Jha, P.N. A Halotolerant Bacterium Bacillus licheniformis HSW-16 Augments Induced Systemic Tolerance to Salt Stress in Wheat Plant (Triticum aestivum). Front. Plant. Sci. 2016, 7, 1890. [CrossRef]

23. Abd_Allah, E.F.; Alqarawi, A.A.; Hashem, A.; Radhakrishnan, R.; Al-Huqail, A.A.; Al-Otibi, F.O.N.; Malik, J.A.; Alharbi, R.I.; Egamberdieva, D. Endophytic bacterium Bacillus subtilis (BERA 71) improves salt tolerance in chickpea plants by regulating the plant defense mechanisms. J. Plant. Interact. 2018, 13, 37-44. [CrossRef]

24. Verslues, P.E.; Sharma, S. Proline metabolism and its implications for plant-environment interaction. Arab. Book 2010, 8, e0140. [CrossRef] [PubMed]

25. Chakdar, H.; Borse, D.N.; Verma, S.; Choudhary, P.; Das, S. Microbial management of crop salinity stress: Mechanisms, applications, and prospects. In Salt Stress, Microbes, and Plant. Interactions: Mechanisms and Molecular Approaches; Akhtar, M., Ed.; Springer: Singapore, 2019; Volume 2. [CrossRef]

26. Hayat, S.; Hayat, Q.; Alyemeni, M.N.; Wani, A.S.; Pichtel, J.; Ahmad, A. Role of proline under changing environments: A review. Plant. Signal. Behav. 2012, 7, 1456-1466. [CrossRef] [PubMed]

27. Chun, S.C.; Paramasivan, M.; Chandrasekaran, M. Proline accumulation influenced by osmotic stress in arbuscular mycorrhizal symbiotic plants. Front. Microbial. 2018, 9, 2525. [CrossRef] [PubMed]

28. Rocha, I.; Ma, Y.; Souza-Alonso, P.; Vosátka, M.; Freitas, H.; Oliveira, R.S. Seed coating: A tool for delivering beneficial microbes to agricultural crops. Front. Plant. Sci. 2019, 10, 1357. [CrossRef]

29. Ma, Y. Seed coating with beneficial microorganisms for precision agriculture. Biotechnol. Adv. 2019, 37, 107423. [CrossRef] [PubMed]

30. Kang, S.; Shahzad, R.; Bilal, S.; Khan, A.L.; Park, Y.G.; Lee, K.-E.; Asaf, S.; Khan, M.A.; Lee, I.-J. Indole-3-acetic-acid and ACC deaminase producing Leclercia adecarboxylata MO1 improves Solanum lycopersicum L. growth and salinity stress tolerance by endogenous secondary metabolites regulation. BMC Microbiol. 2019, 19, 80. [CrossRef]

31. Zhang, S.; Gan, Y.; Xu, B. Mechanisms of the IAA and ACC-deaminase producing strain of Trichoderma longibrachiatum $\mathrm{T} 6$ in enhancing wheat seedling tolerance to $\mathrm{NaCl}$ stress. BMC Plant. Biol. 2019, 19, 1-18. [CrossRef]

32. Egamberdieva, D.; Wirth, S.J.; Alqarawi, A.A.; Abd_Allah, E.F.; Hashem, A. Phytohormones and Beneficial Microbes: Essential Components for Plants to Balance Stress and Fitness. Front. Microbiol. 2017, 8, 2104. [CrossRef] 
33. Egamberdieva, D.; Wirth, S.; Bellingrath-Kimura, S.D.; Mishra, J.; Arora, N.K. Salt-tolerant plant growth promoting rhizobacteria for enhancing crop productivity of saline soils. Front. Microbiol. 2019, 10, 2791. [CrossRef]

34. Ma, Y.; Vosátka, M.; Freitas, H. Editorial: Beneficial microbes alleviate climatic stresses in plants. Front. Plant. Sci. 2019, 10, 595. [CrossRef]

35. Oliveira, R.S.; Rocha, I.; Ma, Y.; Vosátka, M.; Freitas, H. Seed coating with arbuscular mycorrhizal fungi as an ecotechnological approach for sustainable agricultural production of common wheat (Triticum aestivum L.). J. Toxicol. Environ. Health Part A 2016, 79, 329-337. [CrossRef] [PubMed]

36. Rocha, I.; Ma, Y.; Carvalho, M.F.; Magalhães, C.; Janoušková, M.; Vosátka, M.; Freitas, H.; Oliveira, R.S. Seed coating with inocula of arbuscular mycorrhizal fungi and plant growth promoting rhizobacteria for nutritional enhancement of maize under different fertilization regimes. Arch. Agron. Soil Sci. 2019, 65, 31-43. [CrossRef]

37. Wang, Y.; Li, K.; Li, X. Auxin redistribution modulates plastic development of root system architecture under salt stress in Arabidopsis thaliana. J. Plant. Physiol. 2009, 166, 1637-1645. [CrossRef] [PubMed]

38. Iglesias, M.J.; Terrile, M.C.; Windels, D.; Lombardo, M.C.; Bartoli, C.G.; Vazquez, F.; Casalongué, C.A. MiR393 regulation of auxin signaling and redox-related components during acclimation to salinity in Arabidopsis. PLoS ONE 2014, 9, e107678. [CrossRef]

39. Brotman, Y.; Landau, U.; Cuadros-Inostroza, Á.; Takayuki, T.; Fernie, A.R.; Chet, I.; Willmitzer, L. Trichoderma-plant root colonization: Escaping early plant defense responses and activation of the antioxidant machinery for saline stress tolerance. PLoS Pathog. 2013, 9, e1003221. [CrossRef]

40. Contreras-Cornejo, H.A.; Macías-Rodríguez, L.; Alfaro-Cuevas, R.; López-Bucio, J. Trichoderma spp. improve growth of arabidopsis seedlings under salt stress through enhanced root development, osmolite production, and $\mathrm{Na}^{+}$elimination through root exudates. Mol. Plant. Microbe Interact. 2014, 27, 503-514. [CrossRef]

41. Radhakrishnan, R.; Hashem, A.; Abd Allah, E.F. Bacillus: A biological tool for crop improvement through bio-molecular changes in adverse environments. Front. Physiol. 2017, 6, 667. [CrossRef]

42. Wang, X.; Sun, R.; Tian, Y.; Guo, K.; Sun, H.; Liu, X.; Chu, H.; Liu, B. Long- term phytoremediation of coastal saline soil reveals plant species-specific patterns of microbial community recruitment. mSystems 2020, 5, e00741-19. [CrossRef]

43. Elad, Y.; Chet, I.; Henis, Y. A selective medium for improving quantitative isolation of Trichoderma spp. from soil. Phytoparasitica 1981, 9, 59-67. [CrossRef]

44. Yang, L.; Bian, X.; Yang, R.; Zhou, C.; Tang, B. Assessment of organic amendments for improving coastal saline soil. Land Degrad. Dev. 2018, 29. [CrossRef]

45. White, T.J.; Bruns, T.; Lee, S.; Taylor, J. Amplification and direct sequencing of fungal ribosomal RNA genes for phylogenetics. In PCR Protocols: A Guide to Methods and Applications; Innis, M.A., Gelfand, D.H., Sninsky, J.J., White, T.J., Eds.; Academic Press: San Diego, CA, USA, 1990; pp. 315-322.

46. Zarrin, M.; Ganj, F.; Faramarzi, S. Analysis of the rDNA internal transcribed spacer region of the Fusarium species by polymerase chain reaction-restriction fragment length polymorphism. Biomed. Rep. 2016, 4, 471-474. [CrossRef] [PubMed]

47. Lane, J.D. 16S/23S rRNA sequencing. In Nucleic Acid Techniques in Bacterial Systematics; Stackebrandt, E., Goodfellow, M., Eds.; John Wiley and Sons: New York, NY, USA, 1991; pp. 115-175.

48. Altschul, S.F.; Gish, W.; Miller, W.; Myers, E.W.; Lipman, D.J. Basic local alignment search tool. J. Mol. Biol. 1990, 215, 403-410. [CrossRef]

49. Kumar, S.; Stecher, G.; Li, M.; Knyaz, C.; Tamura, K. MEGA X: Molecular evolutionary genetics analysis across computing platforms. Mol. Biol. Evol. 2018, 35, 1547-1549. [CrossRef] [PubMed]

50. Mendoza-Mendoza, A.; Clouston, A.; Li, J.-H.; Nieto-Jacobo, M.F.; Cummings, N.; Steyaert, J.; Hill, R. Isolation and mass production of Trichoderma. Methods Mol. Biol. 2016, 1477. [CrossRef]

51. Bach, J.N.; Bramkamp, M. Flotillins functionally organize the bacterial membrane. Mol. Microbiol. 2013, 88, 1205-1217. [CrossRef]

52. Gordon, S.A.; Weber, R.P. Colorimetric estimation of indoleacetic Acid. Plant. Physiol. 1951, 26, $192-195$. [CrossRef]

53. Wang, Y.; Xi, W.; Wang, Z.; Wang, B.; Xu, X.; Han, M.; Zhou, S.; Zhang, Y. Contribution of ear photosynthesis to grain yield under rainfed and irrigation conditions for winter wheat cultivars released in the past 30 years in North China Plain. J. Integr. Agric. 2016, 15, 2247-2256. [CrossRef] 
54. Singh, P.C.; Nautiyal, C.S. A novel method to prepare concentrated conidial biomass formulation of Trichoderma harzianum for seed application. J. Appl. Microb. 2012, 113, 1442-1450. [CrossRef]

55. Swaminathan, J.; van Koten, C.; Henderson, H.V.; Jackson, T.A.; Wilson, M.J. Formulations for delivering Trichoderma atroviridae spores as seed coatings, effects of temperature and relative humidity on storage stability. J. Appl. Microb. 2016, 120, 425-431. [CrossRef]

56. Rawat, L.; Singh, Y.; Shukla, N.; Kumar, J. Alleviation of the adverse effects of salinity stress in wheat (Triticum aestivum L.) by seed biopriming with salinity tolerant isolates of Trichoderma harzianum. Plant. Soil 2011, 347, 387-400. [CrossRef]

57. Bado, S.; Forster, B.P.; Ghanim, A.M.A.; Jankowicz-Cieslak, J.; Berthold, G.; Luxiang, L. Protocol for screening for salt tolerance in rice. In Protocols for Pre-Field Screening of Mutants for Salt Tolerance in Rice, Wheat, and Barley; Springer International Publishing: Cham, Switzerland, 2016. [CrossRef]

58. Viterbo, A.; Harel, M.; Horwitz, B.A.; Chet, I.; Mukherjee, P.K. Trichoderma mitogen-activated protein kinase signaling is involved in induction of plant systemic resistance. Appl. Environ. Microbiol. 2005, 71, 6241-6246. [CrossRef]

59. Bates, L.S.; Waldren, R.P.; Teare, I.D. Rapid determination of free proline for water-stress studies. Plant. Soil 1973, 39, 205-207. [CrossRef]

60. Fox, J.; Weisberg, S.; Adler, D.; Bates, D.; Baud-Boyy, G.; Ellison, S.; Heilberger, R. Package ‘Car: Companion to Applied Regression. Available online: http://cran-r.project.org/web/packages/car/car.pdf (accessed on 10 June 2020).

61. Lenth, R.V. Least-squares means: The R package lsmeans. J. Stat. Software 2016, 69, 1-33. [CrossRef]

62. Iqbal, M.; Ashraf, M.; Jamil, A.; ur-Rehman, S. Does seed priming induce changes in the levels of some endogenous plant hormones in hexaploid wheat plants under salt stress? J. Integr. Agric. 2006, 48, 181-189. [CrossRef]

63. Iqbal, M.; Ashraf, M. Seed treatment with auxins modulates growth and ion partitioning in salt-stressed wheat plants. J. Integr. Plant. Biol. 2007, 49, 1003-1015. [CrossRef]

64. Leveau, J.H.J.; Lindow, S.E. Utilization of the plant hormone indole-3-acetic acid for growth by Pseudomonas putida strain 1290. Appl. Environ. Microbiol. 2005, 71, 2365-2371. [CrossRef] [PubMed]

65. Backer, R.; Rokem, J.S.; Ilangumaran, G.; Lamont, J.; Praslickova, D.; Ricci, E.; Subramanian, S.; Smith, D.L. Plant Growth-Promoting Rhizobacteria: Context, mechanisms of action, and roadmap to commercialization of biostimulants for sustainable agriculture. Front. Plant. Sci. 2018, 9, 1473. [CrossRef]

66. Stijn, S.; Jos, V.; Roseline, R. Indole-3-acetic acid in microbial and microorganism-plant signaling. FEMS Microbiol. Rev. 2007, 31, 425-448. [CrossRef]

67. Fu, S.F.; Wei, J.Y.; Chen, H.W.; Liu, Y.Y.; Lu, H.Y.; Chou, J.Y. Indole-3-acetic acid: A widespread physiological code in interactions of fungi with other organisms. Plant. Signal. Behav. 2015, 10, e1048052. [CrossRef]

68. Huang, Z.; Zhao, L.; Chen, D.; Liang, M.; Liu, Z.; Shao, H.; Long, X. Salt stress encourages proline accumulation by regulating proline biosynthesis and degradation in Jerusalem artichoke plantlets. PLOS ONE 2013, 8, e62085. [CrossRef]

69. Wang, H.; Tang, X.; Wang, H.; Shao, H.-B. Proline accumulation and metabolism-related genes expression profiles in Kosteletzkya virginica seedlings under salt stress. Front. Plant. Sci. 2015, 6, 792. [CrossRef] [PubMed]

70. Sharma, A.; Shahzad, B.; Kumar, V.; Kohli, S.K.; Sidhu, G.P.S.; Bali, A.S.; Handa, N.; Kapoor, D.; Bhardwaj, R.; Zheng, B. Phytohormones regulate accumulation of osmolytes under abiotic stress. Biomolecules 2019, 9, 285. [CrossRef] [PubMed]

71. Shukla, P.S.; Agarwal, P.K.; Jha, B. Improved salinity tolerance of arachis hypogaea (L.) by the interaction of halotolerant plant growth promoting rhizobacteria. J. Plant. Growth Regul. 2012, 31, 195-206. [CrossRef]

72. Mattioli, R.; Costantino, P.; Trovato, M. Proline accumulation in plants. Plant. Sign. Behav. 2009, 4, $1016-1018$. [CrossRef] [PubMed]

73. Wungrampha, S.; Joshi, R.; Singla-Pareek, S.L.; Pareek, A. Photosynthesis and salinity: Are these mutually exclusive? Photosynthetica 2018, 56, 366-381. [CrossRef]

74. Kalaji, H.M.; Cetner, M.D.; Samborska, I.A.; Lukasik, I.; Oukarroum, A.; Rusinowski, S.; Pietkiewicz, S.; Światek, M.; Dabrowski, P. Effective microorganisms' impact on photosynthetic activity of Arabidopsis plant grown under salinity stress conditions Land Reclamation. Ann. Wars. Univ. Life Sci.-SGGW 2016, 48, 153-163. [CrossRef] 
75. Harman, G.E.; Doni, F.; Khadka, R.B.; Uphoff, N. Endophytic strains of Trichoderma increase plants' photosynthetic capability. J. Appl. Microbiol. 2019. [CrossRef] [PubMed]

76. Vargas, W.A.; Mandawe, J.C.; Kenerley, C.M. Plant-derived sucrose is a key element in the symbiotic association between Trichoderma virens and maize plants. Plant. Physiol. 2009, 151, 792-808. [CrossRef]

77. Samaniego-Gámez, B.Y.; Garruña, R.; Tun-Suárez, J.M.; Kantun-Can, J.; Reyes-Ramírez, A.; Cervantes-Díaz, L. Bacillus spp. inoculation improves photosystem II efficiency and enhances photosynthesis in pepper plants. Chil. J. Agri. Res. 2016, 76, 409-416. [CrossRef]

78. Mohamed, H.I.; Gomaa, E.Z. Effect of plant growth promoting Bacillus subtilis and Pseudomonas fluorescens on growth and pigment composition of radish plants (Raphanus sativus) under $\mathrm{NaCl}$ stress. Photosynthetica 2012, 50, 263-272. [CrossRef]

79. Contreras-Cornejo, H.A.; Macías-Rodríguez, L.; Vergara, A.G.; López-Bucio, J. Trichoderma modulates stomatal aperture and leaf transpiration through an abscisic acid-dependent mechanism in arabidopsis. J. Plant Growth Regul. 2015, 34, 425-432. [CrossRef]

80. Signorelli, S. The fermentation analogy: A point of view for understanding the intriguing role of proline accumulation in stressed plants. Front. Plant. Sci. 2016, 7, 1339. [CrossRef] [PubMed]

81. Kavi Kishor, P.B.; Sreenivasulu, N. Is proline accumulation per se correlated with stress tolerance or is proline homeostasis a more critical issue? Plant. Cell Environ. 2013, 37, 300-311. [CrossRef] [PubMed]

82. López-Bucio, J.; Pelagio-Flores, R.; Herrera-Estrella, A. Trichoderma as biostimulant: Exploiting the multilevel properties of a plant beneficial fungus. Sci. Hortic. 2015, 196, 109-123. [CrossRef]

83. Du Jardin, P. Plant biostimulants: Definition, concept, main categories and regulation. Sci. Hortic. 2015, 196, 3-14. [CrossRef]

84. Fiorentino, N.; Ventorino, V.; Woo, S.L.; Pepe, O.; De Rosa, A.; Gioia, L.; Romano, I.; Lombardi, N.; Napolitano, M.; Colla, G.; et al. Trichoderma-based biostimulants modulate rhizosphere microbial populations and improve N uptake efficiency, Yield, and Nutritional Quality of Leafy Vegetables. Front. Plant. Sci. 2018, 9, 743. [CrossRef]

85. Şesan, T.E.; Oancea, A.O.; Ştefan, L.M.; Mănoiu, V.S.; Ghiurea, M.; Răut, I.; Oancea, F. Effects of foliar treatment with a Trichoderma plant biostimulant consortium on Passiflora caerulea L. yield and quality. Microorganisms 2020, 8, 123. [CrossRef] 